\title{
SAS (SYNTHETIC STRUTURAL ANALYTIC) METHOD IN IMPROVING STUDENT'S READING SKILLS
}

\author{
Muhtarom, Eri Purwanti, M. Yusuf Efendi \\ STIT Pringsewu - Lampung \\ Alamat: Jalan Raya Wonodadi Gadingrejo Pringsewu 35373, Telp. 0729-333091 \\ Website: www.stitpringsewu.ac.id \\ E.mail: muhtarom29@gmail.com, eripurwantimpd@gmail.com
}

\begin{abstract}
The problem in this study is that there are still students who have not been able to read, there are still students who still have difficulty spelling the reading, and there are still low reading skills in students. This study aims to determine the application of the SAS (Synthetic Analytical Structural) method to improve reading skills of grade II students of SDN 1 Wonosari. This type of research is a qualitative method. The research population was class II homeroom teachers, class II students, and principals. The sample of class II students was 13 students. Data collection techniques using interview techniques, observation, documentation. Based on the results of the study, the application of the SAS (Synthetic Analytical Structural) method can improve reading skills of grade II SDN 1 Wonosari students, this can be seen from the progress of students who were not able to read as much as $50 \%$ to $70 \%$. Students who had difficulty spelling a reading from $40 \%$ to $60 \%$. Based on this, the application of the SAS (Synthetic Analytical Structural) method is very helpful in improving the reading skills of grade II students of SDN 1 Wonosari.
\end{abstract}

Keywords: SAS method, reading skills

\section{Abstrak}

Masalah dalam penelitian ini ialah masih ada siswa yang belum mampu membaca, masih ada siswa yang masih kesulitan mengeja bacaan, dan masih rendahnya keterampilan membaca pada diri siswa. Penelitian ini bertujuan untuk mengetahui penerapan metode SAS (Struktural Analitik Sintetik) untuk meningkatkan keterampilan membaca siswa kelas II SDN 1 wonosari. Jenis penelitian ini adalah metode kualitatif. Populasi penelitian guru wali kelas II, Siswa kelas II, kepala sekolah. Sampel siswa kelas II berjumlah 13 siswa. Tehnik pengumpulan data menggunakan tehnik wawancara, observasi, dokumentasi. Berdasarkan hasil penelitian bahwa penerapan metode SAS (Struktural Analitik Sintetik) dapat meningkatkan keterampilan membaca siswa kelas II SDN 1 wonosari, hal ini dilihat dari kemajuan siswa yang tadinya belum mampu membaca sebanyak 50\% menjadi $70 \%$. Siswa yang tadinya kesulitan mengeja bacaan dari $40 \%$ menjadi $60 \%$. Berdasarkan hal tersebut penerapan metode SAS (Struktural Analitik Sintetik) sangat membantu dalam meningkatkan keterampilan membaca siswa kelas II SDN 1 wonosari.

Kata Kunci: Metode SAS, Keterampilan membaca 


\section{A. PENDAHULUAN}

Salah satu keterampilan berbahasa yang mempunyai peran penting dalam kehidupan manusia didukung oleh kemampuan membaca seseorang. Keterampilan membaca tergolong keterampilan yang bersifat aktif reseptif. Aktivitas membaca dapat dikembangkan secara tersendiri, terpisah dari keterampilan mendengarkan dan berbicara. Namun, pada masyarakat yang memiliki tradisi literasi yang telah berkembang, sering kali keterampilan membaca dikembangkan secara terintegrasi dengan keterampilan menyimak dan berbicara (Mulyati, Y. (2014:13).

Membaca adalah keterampilan berbahasa kegiatan melihat tulisan bacaan dan proses memahami isi teks dengan bersuara atau dalam hati. Dalam pelaksanaan keterampilan berbahasa itu harus diberikan secara seimbang dan terpadu (Sri Wahyuni, 2010:9).

Suatu keterampilan membaca, menyimak dan berbiacara dengan mendapatkan informasi dengan cara langsung ke masalah atau fakta kejadian yang dicari merupak unsur penting dalam aktivitas membaca. Beberapa modal utama yang sangat menunjang supaya terampil dalam proses menulis adalah keterampilan dalam membaca, menyimak dan keterampilan berbicara (Sufanti, 2006: 25).

Keterampilan berkonsekuensi dan berbahasa yang diajarkan kepada pembelajar bahasa ialah merupakan suatu keterampilan memabaca. Keterampilan membaca dan keterampilan menyimak itu tergolong keterampilan aktif reseptif, akan tetapi beda cara penyampaian medianya. Keterampilan membaca digunakan untuk mengukur keterampilan memahami keterampilan bahasa tulis, sedangkan keterampilan menyimak digunakan untuk mengukur keterampilan memahami bahasa lisan. Menurut Umi (2016:2), kedua keterampilan berbahasa ini berhubungan erat, karena keduanya merupakan alat untuk menerima komunikasi. Perbedaannya terletak dalam hal jenis komunikasi. Menyimak berhubungan dengan komunikasi lisan, sedangkan membaca berhubungan dengan komunikasi tulis. Dalam hal tujuan, keduanya mengandung persamaan, yaitu memperoleh informasi, menangkap isi, memahami makna komunikasi.

Menurut Samsu Somadoyo (2011), membaca itu bukan proses menghafal kalimat demi kalimat atau kata demi kata yang terdapat dalam teks bacaan, hal yang sangat penting dalam keterampilan membaca ialah Ide pokok bacaan yang baik, menangkap pesan, Informasi, fakta.

Keterampilan membaca memilki manfaat yang sangat banyak, salah satunya ialah menjadikan siswa lebih bijaksana, menjadikan siswa lebih dewasa dalam menjalani kehidupan (Sugiarti, U. , 2012). Adapaun manfaat yang paling umum dari keterampilan membaca ialah siswa dapat belajar dari pengalaman-pengalam orang lain. Sedangkan manfaat khusus keterampilan membaca ialah bahwa orang yang terampil dalam membaca dapat terhindar dari kerusakan jaringan otak dimasa tua. Banyak hal yang bisa diperoleh dari keterampilan membaca yaitu melalui membaca siswa bisa menggali potensi dan bakat mereka, meningkatkan prestasi mereka serta dapat melatih konsentrasi mereka (Pernando, E., 2019).

Dengan melalui membaca seseorang bisa memiliki pengalaman- pengalaman dan informasi tentang ilmu yang terdapat pada buku teks yang tersampaikan oleh penulis. Ide dan gagasan dapat menginspirasi setiap pembaca ketika yang dibaca itu adalah teks yang dapat dimengerti dipahami dan dimaknai. Jika siswa pada usia sekolah tidak segera memiliki keteramipilan membaca, maka siswa akan mengalami banyak kesulitan dalam mempelajari berbagai bidang study pada kelas-kelas brikutnya. Maka dari itu siswa harus belajar membaca agar mereka dapat membaca untuk belajar. Karena apabila siswa banyak membaca, siswa otomatis akan menambah pengetahuan, menambah perbendaraan kata, melatih daya ucap.

Tujuan keterampilan membaca yaitu menguasai dan mengenal sistem tulisan, mengenal dan menggunakan kata sesuai dengan artinya, memahami arti secara eksplisit dalam bacaan pemahaman secara literal, memahami berbagai hubungan dalam berbagai macam kalimat, memahami ide pokok informasi yang penting, dan 
menjelaskan ide penjelas dan ide pokok (Tantri, A. A. S., 2017)

Keterampilan membaca ini merupakan keterampilan yang harus diajarkan kepada siswa sekolah dasar atau madrasah ibtidaiyah, karena dengan membaca siswa dapat memperoleh informasi, menambah pengetahuan dari tulisan-tulisan yang dibacanya. Siswa yang gemar akan keterampilan membaca akan memperoleh wawasan-wawasan dan pengetahuanpengetahuan baru yang akan meningkatkan kecerdasan otaknya sehingga siswa akan mampu tantangan hidup pada masa-masa yang akan mendatang. Keterampilan membaca sebagai proses pembelajaran merupakan sarana pengembangan bagi keterampilan berbahasa lainnya.

Keterampilan membaca dirasa sangat penting dalam ranah pendidikan ditingkat dasar. Namun pada kenyataanya di SDN 1 wonosari keterampilan membaca siswa masih tergolong rendah, Masih ada siswa yang belum mampu membaca, dan masih ada siswa yang masih kesulitan mengeja bacaan. Sehingga peneliti berinisiatif untuk mencari solusi dengan menerapkan metode pembelajaran SAS (Struktural Analitik Sintetik) yang bertujuan untuk meningkatkan keterampilan membaca siswa kelas II SDN 1 wonosari.

Metode pembelajaran SAS merupakan singkatan dari Strutural Analitik Sintetik metode pembelajaran SAS (Struktral Analitik Sintetik) merupakan salah satu jenis metode pembelajaran yang biasa digunakan untuk proses pembelajaran membaca permulaan bagi peserta didik pemula (Halimah, A., 2014). Metode pembelajaran SAS (Struktural Analitik Sintetik) merupakan salah satu jenis metode yang biasa digunakan untuk proses pembelajaran membaca dan menulis permulaan bagi siswa Sekolah dasar atau madrasah ibtidaiyah pemula. Menurut Solchan dkk (2010:6.22) pembelajaran keterampilan membaca dengan metode pembelajaran SAS (Struktural Analitik Sintetik) ini mengawali kegiatan belajaranya dengan cara menyampaikan, menampilkan, menjelaskan, dan memperkenalkannya dengan sebuah kalimat yang utuh. Dalam proses operasionalnya metode pembelajaran SAS (Struktural Analitik Sintetik) mempunyai langkah berlandasan operasional dengan urutan. Struktural menampilkan keseluruhan, guru menampilkan sebuah kalimat pada anak, analitik melakukan proses penguraian anak daiajak untuk megenal konsep kata dan mulai menganalisis kalimat menjadi kata, kata menjadi suku kata dan suku kata menjadi huruf, sintetik melakukan penggabungan kembali . Proses pembelajaran Membaca bagi siswa pemula dengan metode pembelajaran SAS (Struktural Analitik Sintetik) ini mengawali proses pembelajarannya dengan cara menampilkan dan memperkenalkan kalimat-kalimat yang utuh. Unsur bahasa dalam metode SAS (Struktural Analitik Sintetik) ini adalah kalimat. Adapun landasan linguistiknya yaitu bukan tulisan melainkan sebuah ucapan.

Adapun tiga manfat yang merupakan kelebihan dari metode SAS (Struktural Analitik Sintetik) . Manfaat tersebut anatara lain metode SAS (Struktural Analitik Sintetik) sejalan dengan prinsip linguistik (Ilmu Bahasa), metode SAS (Struktural Analitik Sintetik) meningkatkan pertimbangan pengalaman berbahsa siswa, dan metode SAS (Struktural Analitik Sintetik) sesuai dengan prinsip menemukan sendiri dengan Inquiri, siswa dapat memahami dan mengenal sesuatu berdasarkan dengan hasil temuannya sendiri. Dengan begitu, siswa kan merasa lebih percaya diri atas kemampuannya sendiri (Kiky, E. W., 2021).

Dengan membaca anda akan memperoleh informasi yang maksimal dalam waktu yang sesingkat-singkatnya dan dengan tingkat pemahaman isi bacaan yang tinggi juga. Hal-hal yang perlu diperhatikan dalam membaca ialah: 1. tidak membaca kata demi kata 2. biasakan dalam membaca itu per kelompok kata demi kelompok kata 3 . mengulangi kata atau kalimat yang sudah dibaca, 4. Jangan terlalu lama berhenti di awal baris atau pun kalimat karena akan memutuskan hubungan makna antar kalimat maupun antar paragraf, 5. Carilah kata kunci yang menjadi tanda awal terdapatnya sebuah gagasan utama pada sebuah kalimat, 6 . Abaikan juga kata-kata lugas yang sifatnya itu berulang-ulang, misalnya kepada, yang ,di, dari, dan lain sebagainya. Tujuan dalam membaca ini adalah untuk meminimalisir penggunaan waktu agar dapat waktu dalam membaca itu relatif singkat dan kita tetap 
mampu untuk mendapatkan hasil serta juga memahami bacaan yang kita baca.

Teknik membaca cepat metode pembelajaran SAS (Struktural Analitik Sintetik) adalah suatu teknik untuk dapat mencari gagasan pokok atau hal-hal penting lainnya yang ada di dalam bacaan. Metode pembelajaran SAS (Struktural Analitik Sintetik) bisa dilakukan apabila : 1. Ingin mengenali topik bacaan, 2.Ingin melakukan suatu penyegaran akan apa yang pernah dibaca, 3.Ingin mendapatkan bagian penting dari suatu bacaan tanpa membaca keseluruhan, 4.Ingin mengetahui pendapat seseorang dengan secara garis besar atau umum saja. Metode pembelajaran SAS (Struktural Analitik Sintetik) adalah metode pembelajaran membaca yang dimulai dengan langkah bercerita sambil menunjukkan gambar pendukung. Setelah itu siswa diajak untuk membaca gambar tersebut, yang dilanjutkan dengan membaca kalimat yang ada dibawah gambar. Selanjutnya gambar dilepas atau diambil dan tinggal lah kalimatnya. Siswa berlatih membaca kalimat tanpa bantuan gambar (proses struktural). (Hidayah Nurul, 2016:85-102). Kalimat tersebut lalu dianalisis menjadi kata, suku kata, hurufhuruf (proses analitik).Langkah terakhir adalah menggabungkan kembali huruf-huruf menjadi suku kata, suku kata menjadi kata, dan kata-kata menjadi kalimat (proses sintetik). Penggunaan metode pembelajaran SAS (Struktural Analitik Sintetik) dirasa sangat penting diantaranya memeriksa sebuah bab didalam sebuah buku sebelum mempelajari nya dengan jenis dan dapat memperoleh sebuah gagasan mengenai cakupan secara umum bab tersebut menyampel atau mencari contoh menentukan hanya tersebut bernilai memeriksa, menemukan pandangan pengarang.

Langkah-langkah membaca menggunakan metode pembelajaran SAS (Sturktural Analitik Sintetik) : membuat pertanyaan tentang apa yang akan kita cari dari suatu buku, Telusuri daftar isi atau pun kata pengantar, apakah informasi yang kita butuhkan itu ada didalam bacaan tersebut, focus, telusuri dengan kecepatan tinggi tiaptiap paragraf atau juga subbab, berhentilah saat anda sudah merasa menemukan apa yang anda cari, bacalah dengan kecepatan normal, serta juga pahami dengan baik apa yang anda cari.

\section{B. TUJUAN}

1. Untuk mengetahui penerapan metode pembelajaran SAS (Struktural Analitik Sintetik) untuk meningkatkan keterampilan membaca siswa kelas II SDN 1 Wonosari.

2. Untuk mengetahui Faktor pendukung danpenghambat metode pembelajaran SAS (Struktural Analitik Sintetik) untuk meningkatkan keterampilan membaca siswa kelas II SDN 1 Wonosari.

\section{METODE}

Metode penelitian yang digunakan dalam penelitian ini adalah penelitian kualitatif penelitian metode kualitatif yang dilaksanakan di kelas II SDN 1 wonosari tahun 2020 semester ganjil. Tehnik pengumpulan data melalui observasi, wawancara, dan dokumentasi.Populasi data penelitian ini berjumlah 15 orang. Sampel dalam penelitian ini berjumlah 13 siswa. Tehnik penyajian sampel dengan porposive sapling.

\section{HASIL DAN PEMBAHASAN}

Penelitian ini menggunakan metode pembelajaran SAS yaitu merupakan kepanjangan dari Struktural Analitik Sintetik yang dimana struktural itu berarti keseluruhan, Sintetik berarti penguraian,analitik berarti menggabungkan kembali. Metode pembelajaran SAS (Struktural analitik sintetik) adalah pembelajaran membaca permulaan mnggunakan proses penguraian kalimat menjadi kata, kata menjadi suku kata suku kata menjadi huruf Fonem itu kemudian dilanjutkan dengan proses sintetis. (Dwimayanti 2013:18).

Pengertian metode pembelajaran SAS (Struktural Analitik Sintetik) adalah suatu pendekatan cerita yang disertai dengan gambar yang didalamnya terkandung unsur struktur anlitik sintetik.(Supriyadi 2012).

Metode pembelajaran SAS (Struktural Analitik Sintetik) adalah metode untuk proses pembelajaran keterampilan membaca yang diawali dengan cara menampilkan dan 
memperkenalkan sebuah kalimat yang utuh. Untuk pertama kali siswa diajarkan sebuah struktur-struktur kalimat. Kemudian para siswa diajak untuk mengenal konsep kata. Kemudian kalimat-kalimat yang masih utuh diuraikan ke dalam satuan-satuan bahasa yang lebih kecil yaitu kata. Proses penguraian ini terus berlanjut sehingga satuan bahasa terkecil yang tidak dapat diuraikan lagi yaitu huruf-huruf.

Metode pembelajaran SAS (Struktural Analitik Sintetik) adalah suatu cara untuk mengajarkan keterampilan membaca pada siswa sekolah dasar atau madrasah ibtidaiyah dengan cara menampilkan suatu kalimat utuh yang kemudian diurai menjadi kata sehingga menjadi huruf-huruf yang berdiri sendiri dan menggabungkan kembali menjadi kalimat yang utuh. Adapun hal tersebut dimaksudkan untuk membangun konsep-konsep kebermaknaan pada diri siswa. Pada proses pembelajaran keterampilan membaca dengan metode SAS (Struktural Analitik Sintetik), sturutur kalimat yang disajikan sebagai bahan pembelajaran adalah sturktur kalimat yang akan digali dengan pengalaman-pengalaman berbahasa si pembelajar itu sendiri, sehingga keterampilan berbahasa siswa akan meningkat.

Metode pembelajaran SAS (Struktural Analitik Sintetik) adalah metode pembelajaran yang digunakan untuk belajar membaca disekolah dasar atau madrasah ibtidaiyah. Dalam Proses oprasionalnya metode pembelajaran SAS (Struktural Analitik Sintetik) mempunyai langkahlangkah yang berlandaskan operasional dengan langkah-langkah berikut: Struktural akan menampilkan keseluruhan, dan akan memperkenalkan kalimat yang utuh, Analitik melakukan penguraian, sintetik akan melakukan penggabungan kepada bentuk semula.

Langkah-langkah metode pembelajaran SAS (Struktural Analitik Sintetik) yaitu sebagai berikut: Guru menampilkan keseluruhan kalimat (S), kemudian guru melakukan penguraian kalimat (A), setlah itu guru menampilkan keseluruhan kalimat pada struktur kalimat (S). (Suhendi 2013).

Hal tersebut dimaksudkan untuk membangun konsep kebermaknaan pada diri siswa. Akan lebih baik jika struktur kalimat yang disajikan sebagai bahan keterampilan membaca dengan metode pembelajaran SAS (Struktural Analitik Sintetik) ini adalah struktur kalimat yang digali dari pengalaman berbahsa si anak tersebut.

Berikut ini proses penganalisisan dan proses penguraian dalam pembelajaran keterampilan membaca menggunakan metode pembelajaran SAS (Struktural Analitik Sintetik) Yaitu: Kalimat menjadi kata, kata menjadi suku-suku kata, suku kata menjadi huruf-huruf.

Solchan dkk (2010:23) mengemukakan beberapa manfaat yang dianggap sebagai kelebihan dari metode SAS ini, diantarnya sebagai berikut: Metode pembelajaran SAS (Struktural Analitik Sintetik) ini sejalan dengan prinsip lingusitik (Ilmu bahasa) yang memndang satuan bahasa terkecil untuk berkomunikasi, Metode pembelejaran SAS (Struktural Analitik Sintetik) ini mempertimbangkan pengelaman berbahsa siswa. Oleh karena itu pembelajaran akan lebih bermakna bagi siswa karena bertolak dari sesuatu yang dikenal dan diketahui anak, Metode pembelajaran SAS (Struktural Analitik Sintetik) ini sesuai dengan inquiri, sehingga anak mengenal dan memahami sesuatu berdsarkan hasil temuannya sendiri.

Adapun langkah-langkah metode pembelajaran SAS (Struktural Analitik Sintetik) dalam pelaksanaanya yaitu, metode ini dilakukan melalui dua tahap yaitu tanpa buku dan menggunakan buku.

Langkah-langkah metode pembelajaran SAS (Struktural Analitik sintetik) untuk meningkatkan keterampilan membaca tanpa buku: Guru merekam bahasa siswa, guru menampilkan gambar sambil bercerita kepada siswa, kemudian siswa diajak membaca gambar, kemudian membaca gambar dengan kartu kalimat.

Langkah-langkah metode pembelajaran SAS (Struktural Analitik Sintetik) untuk meningkatkan keterampilan membaca dengan buku: Siswa diberikan buku paket yang sama, dan siswa diberi kesempatan untuk melihat isi dari buku tersebut oleh guru, guru menjelaskan 
mengenai isi dari buku paket yang telah diberikan untuk siswa, Siswa diberi penjelasan mengenai fungsi angkaangka yang menunjukan halaman bukubuku, guru mengajak para siswanya untuk memusatkan perhatian pada salah satu tema yang terdapat pada halaman buku paket tersebut, kemudian jika bacaan itu disertai gambar guru akan terlebih dahulu menjelaskan dan menceritakan mengenai gambar yang dimaksud, kemudian setelah itu guru memulai proses pembelajaran dengan cara memberikan contoh sebuah pola kalimat dengan intonasi dan lafal yang benar, metode pembelajaran SAS (Struktural Analitik Sintetik) ini akan lebih cocok untuk pembelajaran untuk keterampilan membaca dibanding dengan metode-metode pembelajaran yang lain sebab metode pembelajaran SAS (Struktural Analitik Sintetik) ini bertujuan juga untuk merancang bahasa yang bahasa-bahasa yang sesuai dengan karakteristik-karakteristik siswa itu sendiri.

Metode pembelajaran SAS (Struktural analitik sintetik) itu baik diterapkan di Sekolah dasar, madrasah ibtidaiyah terutama untuk yang sedang belajar membaca permulaan, karena metode pembelajaran SAS (Struktural Analitik Sintetik) ini dalam prosesnya bersifat mengajarkan anak membaca secara bertahap mulai dari mengenal huruf, suku kata, dan kalimat.

Metode pembelajaran SAS (Struktural Analitik Sintetik) memulai pembelajaran membaca permulaan dari kalimat utuh kemudian ke unsur-unsur yang lebih kecil. Dalam metode pembelajaran SAS (Struktural Analitik Sintetik), anak lebih dulu diperkenalkan pada suatu kalimat. Kalimat tersebut selanjutnya dirinci menjadi kata-kata, dipecah lagi menjadi suku kata, dan selanjutnya dipecah-pecah lagi menjadi huruf-huruf.

Dalam pelaksanaan metode pembelajaran SAS (Struktural Analitik Sintetik) ini, bukan hanya guru yang aktif namun siswa sangat berperan aktif dalam proses pembelajaran dimana siswa dituntut terampil dalam mencari huruf, suku kata, kata dan menjadikannya sebuah kalimat, sehingga mereka mampu membaca dengan baik.

Keunggulan dan Kelemahan Metode pembelajaran SAS (Struktural Analitik Sintetik)

\section{Keunggulan}

1. Metode pembelajaran SAS (Struktural Analitik Sintetik) ini menerapkan prinsip ilmu bahasa namun (Linguistik) bahwa bentuk bahasa yang terkecil adalah kalimat. Bagian kalimat adalah kata, suku kata, dan akhirnya fonem.

2. Metode pembelajaran SAS (Struktural Analitik Sintetik) ini mempertimbangkan pengalaman berbahasa anak, pengalaman bahasa anak dijadikan titik tolak belajar bahasa karena dengan penagalaman bahasa anak sudah merasa akrab dengan sesuatu yang telah diketahui sebelumnya.

3. Metode pembelajaran SAS (Struktural Analitik Sintetik) ini menganut prinsip menemukan sendiri (Inkuiri). Anak mempunyai rasa kepercayaan pada kemampuan sendiri. Anak secara prbadi mengetahui kemampuan dalam membaca. Sehingga anak yang kurang mampu keteramplilannya dalam mebaca mereka dapat memperbaiki diri untuk belajar membaca lebih baik.

Kelemahan

1. Membutuhkan waktu lebih banyak dan harus lebih kreatif. Tuntutan semacam ini dipandang sangat sukar untuk kondisi pengajar saat ini.

2. Menyebabkan anak menghafal bacaan tanpa mengenal huruf. Misalnya anak terbiasa melihat bacaan yang, ini, itu dan lainnya. Anak tahu bacaan tersebut tetapi anak tidak mengenal huruf-huruf dan bacaan tersebut.

3. Membutuhkan banyak sarana yang harus dipersiapkan untuk pelaksanaan metode pembelajaran SAS (Struktural Analitik Sintetik) ini untuk sekolah tertentu dirasa sukar. 
4. Metode Pembelajaran SAS (Struktural Analitik Sintetik) ini cenderung agak sukar diajarkan oleh pengajar metode pembelajaran SAS (Struktural Analitik Sintetik) maka disana sini metode ini tidak dilaksanakan.

Metode pembelajaran SAS (Struktural Analitik Sintetik) memiliki kelebihan yang dapat membantu anak dalam meningkatkan keterampilan membaca. Metode pembelajaran SAS (Struktural Analitik Sintetik) ini dapat mengaktifkan siswa serta bahasa yang digunakan adalah bahasa anak sehingga lebih mudah dipahami oleh siswa serta dengan menggunakan metode pembelajaran SAS (Struktural Analitik Sintetik) ini siswa akan lebih memahami. (Kurniawan., 2016:149-157).

Keterampilan Membaca merupakan suatu proses yang dilakukan serta dipergunakan oleh pembaca untuk memperoleh pesan yang hendak disampaikan oleh penulis melalui media kata-kata atau bahn tulis. Gilet dan template menyatakan bahwa membaca adalah kegiatan fisual, berupa serangkaian gerakan mata dalam mengikuti baris-baris tulisan, pemusatan penglihatan pada kata dan kelompok kata untuk memperoleh pemahaman terhadap bacaan. (Samsu Somadayo,2011:4-5).

Keterampilan membaca memiliki peranan yang sangat penting karena keberhasilan belajar siswa dalam mengikuti proses pembelajaran disekolah sangat ditentukan oleh penguasaan keterampilan membaca. siswa yang mampu membaca dengan baik akan mengalami peningkatan dalam mengikuti pembelajaran disekolah atau kelasnya.

Berdasarkan hasil penelitian bahwa penerapan metode pembelajaran SAS (Struktural Analitik Sintetik) dapat meningkatkan keterampilan membaca siswa kelas II sekolah dasar negeri 1 wonosari, hal ini dilihat dari kemajuan siswa yang tadinya belum mampu membaca sebanyak 50\% menjadi $70 \%$. Siswa yang tadinya kesulitan mengeja bacaan dari $40 \%$ menjadi $60 \%$. Berdasarkan hal tersebut penerapan metode pembelajaran SAS (Struktural Analitik Sintetik) sangat membantu dalam meningkatkan keterampilan membaca siswa kelas II SDN 1 wonosari.

Faktor pendukung dan penghambat metode pembelajaran SAS (Struktural Analitik Sintetik) untuk meningkatkan keterampilan membaca siswa kelas II SDN 1 wonosari yaitu:

a. Faktor pendukung
1. Tersedianya perpustakaan yang memadai.

2. Tenaga pendidik memberi motivasi kepada peserta didik untuk membaca.
3. Tenaga pendidik menggunakan Proses pembelajara yang menarik.

b. Faktor penghambat

1. Sekolah Belum melaksanakan kegiatan-kegiatan yang menunjang peningkatan keterampilan membaca.

2. Sekolah belum memiliki tempat khusus untuk membaca selain diperpustakaan.

3. Minat yang rendah.

\section{E. PENUTUP}

\section{Kesimpulan}

Berdasarkan hasil penelitian dan pembahasan dapat disimpulkan bahwa penerapan metode pembelajaran SAS (Struktural Analitik Sintetik) untuk meningkatkan keterampilan membaca siswa kelas II sekolah dasar negeri 1 wonosari. hal ini dilihat dari kemajuan siswa yang tadinya belum mampu membaca sebanyak 50\% menjadi $70 \%$. Siswa yang tadinya kesulitan mengeja bacaan dari $40 \%$ menjadi $60 \%$. Berdasarkan hal tersebut penerapan metode pembelajaran SAS (Struktural Analitik Sintetik) sangat membantu dalam meningkatkan keterampilan membaca siswa kelas II sekolah dasar negeri 1 wonosari. Hal ini terlihat dari indikator observasi aktivitas siswa selama proses pembelajaran membaca dari beberapa indikator yang diamati hampir semua aspek sudah dalam kategori baik

\section{Saran}

Kepada guru maupun calon guru diharapkan untuk menerapkan metode pembelajaran SAS (Struktural Analitik Sintetik). Tetapi dalam pelaksanaanya guru atau calon guru 
agar memperhatikan waktu yang digunakan dalam pembelajaran, kondisi siswa yang ada dalam kelas dan penguasaan metode pembelajaran, agar lebih efektif dan mudah diikuti oleh siswa.

\section{DAFTAR PUSTAKA}

Dwimayanti. 2013. Penerapan Metode pembelajaran SAS(Struktural Analitik Sintetik) untuk meningkatkan keterampilan membaca dan hasil belajar siswa kelas II pada mata pelejaran bahasa indonesia diSD. Jurnal FKIP PGSD. Singaraja: Universitas pendidikan Ganesh.

Halimah, A. (2014). Metode Pembelajaran Membaca dan Menulis Permulaan di SD/MI. AULADUNA: Jurnal Pendidikan Dasar Islam, 1(2), 190200.

Hidayah Nurul. Peningkatan Keterampilan membaca dengan menggunakan metode pembelajaran SAS(Struktural Analitik Sintetik) Mata pelajaran bahasa indonesia pada peserta didik kelas II C semester ii di MIN 6 Bandar Lampung T.A 2015/2016. Terampil Jurnal pendidikan dan pembelajaran dasar Volume 3 Nomor 1 juni 2016. 85-102.

KIKY, E. W. (2021). PENGEMBANGAN BUKU CERITA BERGAMBAR BERBASIS METODE SAS (STRUKTURAL ANALITIK SINTETIK) MENINGKATKAN KEMAMPUAN MEMBACA PERMULAAN KELAS 1 PADA TEMA DIRIKU (Doctoral dissertation, UIN RADEN INTAN LAMPUNG).

Kurniawan, otang \& Noviana Eddy. (2016). Metode pembelajaran membaca SAS (Struktural Analitik Sintetik) Dalam meningkatkan keterampilan membaca permulaan di kelas 1 SDN 79 Pekan baru. Jurnal primary program studi pendidikan guru sekolah dasar fakultas keguruan dan ilmu pendidikan universitas riau volume 5 , Nomor 2.149-157.

Mulyati, Y. (2014). Hakikat keterampilan berbahasa. Jakarta: PDF Ut. ac. id hal, 1 .
Pernando, E. (2019). Peran Orang Tua Dalam Meningkatkan Kemampuan Membaca dan Menulis bagi Anak di Desa Kota Padang Kecamatan Manna Kabupaten Bengkulu Selatan (Doctoral dissertation, IAIN BENGKULU).

Samsu Somadayo, 2011, Strategi dan Tehnik pembelajaran membaca,Graha Ilmu, Yogyakarta.

Solchan T. W., dkk. (2010). Pendidikan Bahasa Indonesia di SD. Jakarta: Universitas Terbuka

Sri Wahyuni. 2010. Cepat Bisa Membaca,. Gramedia, Jakarta.

Sufanti, 2006. keterampilan membaca, menyimak dan berbicara itu merupakan modal untuk terampil menulis, Ejurnal pendidikan jurusan PGSD FIP Universitas pendidikan Ganesha singaraja Volume 4, Nomor 89-104.

Sugiarti, U. (2012). Pentingnya Pembinaan Kegiatan Membaca Sebagai Implikasi Pembelajaran Bahasa Indonesia. Basastra, 1(1).

Supriyadi, 2012. pengertian metode pembelajaran SAS struktural analitik sintetik, https://Fatkhan.web.id/pengertianmetode-pembelajaran-strukturalanalitik-sintetik-sas/ diakses tgl 8 februari 2021

Tantri, A. A. S. (2017). Hubungan antara Kebiasaan Membaca dan Penguasaan Kosakata dengan Kemampuan Membaca Pemahaman. ACARYA PUSTAKA: Jurnal Ilmiah Perpustakaan dan Informasi, 2(1).

Umi Hijriyah, U. (2016). Menyimak Strategi Dan Implikasinya Dalam Kemahiran Berbahasa. 